\title{
HUBUNGAN TINGKAT PENGETAHUAN IBU HAMIL TENTANG TABLET BESI DENGAN MOTIVASI IBU MENGKONSUMSI TABLET BESI DI PMB NI LUH PUTU YUNIASIH, S.ST
}

\author{
The Relationship of The Pregnan Women's Iron Tablet Knowledge Level with \\ Motivation to Consume Iron Tablet in BPM Luh Putu Yuniasih, S.ST
} \author{
Agung Manik Karuniadi ${ }^{4}$ \\ ${ }^{1}$ Kebidanan' Stikes Bina Usada Bali, Indonesia \\ ${ }^{2}$ Kebidanan' Stikes Bina Usada Bali, Indonesia \\ ${ }^{3}$ Kebidanan' Stikes Bina Usada Bali, Indonesia \\ ${ }^{4}$ Kebidanan' Stikes Bina Usada Bali, Indonesia
}

Putu Ayu Dina Saraswati ${ }^{1}$, Luh Putu Widiastini², Ni Putu Mirah Yunita Udayani ${ }^{3}$, I Gusti

Korespondensi: Putu Ayu Dina Saraswatidan dhiinaadriana@gmail.com

\begin{abstract}
ABSTRAK
Latar Belakang: Zat besi merupakan mineral yang diperlukan oleh semua sistem biologis di dalam tubuh, kekurangan zat besi disebut anemia defisiensi besi. Ibu hamil dengan anemia memiliki risiko lebih tinggi mengalami kelelahan saat bersalin, perdarahan serta melahirkan bayi dengan anemia defisiensi besi Kurangnya motivasi ibu untuk mengkonsumsi tablet zat besi, sering disebabkan oleh pengetahuan yang dimiliki oleh ibu tentang efek samping yang ditimbulkan oleh tablet zat besi tersebut Tujuan: Tujuan penelitian ini adalah untuk mengetahui hubungan antara tingkat pengetahuan ibu hamil tentang tablet besi dengan motivasi ibu mengkonsumsi tablet besi di PMB Luh Putu Yuniasih, S.ST. Metode: Penelitian ini adalah deskriptif korelatif dengan pendekatan cross sectional. Jumlah sampel adalah 40 responden, yang dilakukan di PMB Luh Putu Yuniasih, S.ST dari bulan Oktober-Novermber 2021. Hasil: Berdasarkan hasil penelitian diperoleh tingkat pengetahuan responden sebagian besar kategori kurang dan tingkat motivasi kategori cukup. Nilai korelasi Spearman Rho sebesar 0,608 dan $p$ value $=0,00$, yang artinya Ha diterima atau ada hubungan tingkat pengetahuan ibu hamil dengan motivasi ibu mengkonsumsi tablet besi. Kesimpulan: Ada hubungan antara pengetahuan dan motivasi ibu mengkonsumsi tablet besi di PMB Luh Putu Yuniasih, S.ST, hal ini menunjukkan pengetahuan merupakan penentu adanya motivasi pada ibu hamil dalam mengkonsumsi tablet besi.
\end{abstract}

Kata Kunci: Pengetahuan; Motivasi; Zat Besi.

\begin{abstract}
Background: Iron is a mineral needed by all biological systems in the body, iron deficiency is called iron deficiency anemia. Pregnant women with anemia have a higher risk of experiencing fatigue during childbirth, bleeding and giving birth to babies with iron deficiency anemia. Lack of motivation for mothers to take iron tablets, is often caused by the knowledge possessed by mothers about the side effects caused by iron tablets.Objective: The purpose of this study was to determine the relationship between the level of knowledge of pregnant women
\end{abstract}


about iron tablets with the motivation of mothers to consume iron tablets at PMB Luh Putu Yuniasih, S.ST. Methods: This research is a descriptive correlation with a cross sectional approach. The number of samples was 40 respondents, which was conducted at PMB Luh Putu Yuniasih, S.ST from October-November 2021. Results: Based on the results of the study, most of the respondents' knowledge level was in the less category and the motivation level was in the sufficient category. The Spearman Rho correlation value is 0.608 and $p$ value $=0.00$, which means Ha is accepted or there is a relationship between the knowledge level of pregnant women and the mother's motivation to consume iron tablets. Conclusion: There is a relationship between knowledge and motivation of mothers to consume iron tablets at PMB Luh Putu Yuniasih, S.ST, this shows that knowledge is a determinant of motivation in pregnant women in consuming iron tablets.

Keywords: Knowledge; Motivation; Iron.

\section{PENDAHULUAN}

Mortalitas dan morbiditas merupakan masalah besar di negara berkembang. setiap jam, diperkirakan dua ibu mengalami kematian karena komplikasi selama hamil atau melahirkan. Kematian akibat kehamilan, persalinan, dan nifas yang terjadi di negara miskin sekitar 25-50\%. WHO memperkirakan di seluruh dunia setiap tahunnya lebih dari 585.000 meninggal saat hamil atau bersalin (Kemenkes RI, 2012).

Angka Kematian Ibu (AKI) merupakan salah satu indikator untuk melihat keberhasilan upaya kesehatan di suatu negara (Cherry, 2015). Indikator ini juga mampu menilai derajat kesehatan masyarakat, karena sensitifitasnya terhadap perbaikan pelayanan kesehatan, baik dari sisi aksesibilitas maupun kualitas (Prabhakara, 2019). Menurut Badan Pusat Statistik, (2015), angka kematian ibu di Indonesia mencapai 305/100.000 per kelahiran hidup. Angka Kematian Ibu (AKI) saat ini masih jauh dari target Tujuan Pembangunan kelanjutan/Sustainable Development Goals (SDGs) yakni 70 per 100.000 kelahiran hidup pada tahun 2030 (Susiana, 2019).

Tingginya angka tersebut disebabkan antara lain oleh keadaan kesehatan dan gizi ibu yang rendah selama masa hamil, terlihat dengan masih banyaknya kejadian anemia defisiensi besi pada ibu hamil yaitu 63.5\% (Ari et al., 2015). Menurut World Health Organization (WHO), kematian ibu berkaitan dengan anemia dalam kehamilan di negara berkembang sebanyak 40\% (BPPD , 2019). Anemia adalah suatu kondisi di mana jumlah sel darah merah atau kapasitas sel darah merah membawa oksigen tidak cukup untuk memenuhi kebutuhan fisiologis. Ibu hamil dengan anemia memiliki risiko lebih tinggi melahirkan bayi dengan anemia defisiensi besi yang bisa bertahan sepanjang usia awal anak dan menghambat pertumbuhan selsel otak anak serta sel-sel tubuh lainnya, yang mengakibatkan keterlambatan pertumbuhan dan perkembangan (Badan Pusat Statistik, 2017).

Salah satu upaya yang dilakukan untuk mengatasi anemia pada ibu hamil adalah pemberian tablet zat besi minimal 90 tablet 
semasa kehamilannya (Kemenkes RI, 2020). Pemberian tablet zat besi dan Vitamin C dua kali sehari untuk anemia ringan, sedangkan pemberian tablet zat besi dan Vitamin $\mathrm{C}$ tiga kali sehari untuk anemia berat (Nurohmi et al., 2021),

Zat besi merupakan mineral yang diperlukan oleh semua sistem biologis di dalam tubuh (Paendong et al., 2016). Pada ibu hamil zat besi berfungsi untuk stabilitas kadar hemoglobin dalam darah supaya aliran oksigen ke janin optimal, menghindari kelelahan saat bersalin sehingga tidak terjadi perdarahan yang berlebihan (Prasetyani et al., 2020). Kebutuhan zat besi pada ibu selama kehamilan ialah $800 \mathrm{mg}$ besi, diantaranya $300 \mathrm{mg}$ untuk janin dan plasenta dan $500 \mathrm{mg}$ untuk pertambahan eritrosit ibu (Paulo, 2019).

Ibu hamil mendapatkan tablet zat besi, namun tidak semua mengkonsumsi secara rutin, hal ini bisa disebabkan karena kurangnya motivasi ibu untuk mengkonsumsi tablet zat besi, kurangnya motivasi sering disebabkan oleh pengetahuan yang dimiliki oleh ibu tentang efek samping yang ditimbulkan oleh tablet zat besi tersebut (Khoiriah, 2020). Dampak yang diakibatkan dari mengkonsumsi tablet zat besi seperti sembelit dan mual (Susiloningtyas, 2012), hal ini menyebabkan ibu hamil enggan untuk mengkonsumsi tablet besi, selain itu faktor sosial ekonomi yang rendah juga memegang peranan penting kaitannya dengan asupan gizi ibu selama hamil (Lestari, 2017).

Berdasarkan hal-hal di atas penulis merasa tertarik untuk mengetahui hubungan pengetahuan ibu hamil dengan motivasi ibu mengkonsumsi tablet besi di PMB Luh Putu Yuniasih, S.ST.

\section{TUJUAN PENELITIAN}

Secara umum tujuan penelitian ini adalah untuk mengetahui hubungan antara tingkat pengetahuan ibu hamil dengan motivasi ibu mengkonsumsi tablet besi di PMB Luh Putu Yuniasih, S.ST.

\section{METODE PENELITIAN}

Pada penelitian ini, peneliti menggunakan desain deskriptif korelatif, dengan pendekatan crosssectional. Jumlah sampel dalam penelitian ini adalah 40 responden. Menggunakan teknik purposive sampling. Penelitian ini dilakukan di PMB Luh Putu Yuniasih, S.ST dari bulan Oktober-Novermber 2021. Alat pengumpulan data menggunakan kuesioner untuk mengukur tingkat pengetahuan dan motivasi ibu mengkonsumsi tablet besi.

Data dianalisis menggunakan SPSS, yang meliputi Analisis Univariat yang dilakukan secara deskriptif, analisis disajikan dalam bentuk tabel dan narasi hasil interpretasi dan Analisis Bivariat dilakukan untuk mengetahui keterkaitan serta kemaknaan variabel bebas dan terikat. Uji statistik yang digunakan adalah uji Spearman Rank.

\section{HASIL PENELITIAN}

Tabel 1. Karakteristik Responden Berdasarkan Umur

\begin{tabular}{ccc} 
Umur & Frekuensi (f) & Persentase (\%) \\
\hline$<20$ tahun & 4 & 10 \\
$20-35$ tahun & 35 & 87,5 \\
$>35$ tahun & 1 & 2,5 \\
Total & 40 & 100 \\
\hline
\end{tabular}


Putu Ayu Dina Saraswati: Hubungan Tingkat Pengetahuan Ibu Hamil tentang Tablet Besi dengan Motivasi Ibu Mengkonsumsi Tablet Besi di PMB Ni Luh Putu Yuniasih, S.ST.

Berdasarkan tabel di atas, dijelaskan bahwa dari 40 responden, responden berumur $<20$ tahun yaitu sebanyak 4 orang atau (10\%), umur 20-35 tahun sebanyak 35 orang atau $(87,5 \%)$, dan umur $>35$ tahun sebanyak 1 orang atau (2,5\%).

Tabel 2. Distribusi Frekuensi Responden berdasarkan Pendidikan

\begin{tabular}{ccc} 
Pendidikan & Frekuensi (f) & Persentase (\%) \\
\hline SD & 5 & 12,5 \\
SMP & 11 & 27,5 \\
SMA & 21 & 52,5 \\
Akademi/PT & 3 & 7,5 \\
Total & 40 & 100 \\
\hline
\end{tabular}

Berdasarkan tabel di atas, dapat dijelaskan bahwa dari 40 responden, yang berpendidikan SD sebanyak 5 orang atau (12,5\%), SMP sebanyak 11 orang atau $(27,5 \%)$, SMA sebanyak 21 orang atau (52,5\%) dan akademi/PT sebanyak 3 orang $(7,5 \%)$.

Tabel 4. Distribusi Frekuensi Responden Menurut Tingkat Pengetahuan

\begin{tabular}{ccc} 
Tingkat Pengetahuan & Frekuensi (f) & Persen (\%) \\
\hline Baik & 7 & 17,5 \\
Cukup & 21 & 52,5 \\
Kurang & 12 & 30 \\
Total & 40 & 100 \\
\hline
\end{tabular}

Berdasarkan tabel di atas, dapat dijelaskan bahwa dari 40 responden yang memiliki tingkat pengetahuan baik sebanyak 7 orang atau $17,5 \%$, tingkat pengetahuan cukup sebanyak 12 orang atau $30 \%$ dan sebanyak 21 orang atau 52,5\% tingkat pengetahuan kurang.
Tabel 5. Distribusi Frekuensi Responden berdasarkan Motivasi

\begin{tabular}{ccc} 
Motivasi & Frekuensi (f) & Persen (\%) \\
\hline Cukup & 24 & 60 \\
Kuat & 15 & 37,5 \\
Tidak Kuat & 1 & 2,5 \\
Total & 40 & 100 \\
\hline Berdasarkan & tabel & diatas
\end{tabular}
dijelaskan bahwa dari 40 responden dengan motivasi kategori cukup sebanyak 24 orang atau $60 \%$, motivasi kuast sebanyak 15 orang atau $37,5 \%$, dan motivasi tidak kuat sebanyak 1 orang atau $2,5 \%$.

Tabel 6. Tabel Silang Tingkat Pengetahuan Dengan Motivasi

\begin{tabular}{|c|c|c|c|c|c|}
\hline & & & Motivasi & & Total \\
\hline & & Cukup & Kuat & $\begin{array}{l}\text { Tidak } \\
\text { Kuat }\end{array}$ & \\
\hline Tingkat & Baik & 4 & 3 & 0 & 7 \\
\hline & & 57,1 & $42,9 \%$ & $0 \%$ & $100 \%$ \\
\hline & Cukup & 3 & 9 & 0 & 12 \\
\hline & & $25 \%$ & $75 \%$ & $0 \%$ & $100 \%$ \\
\hline & Kurang & 17 & 3 & 1 & 21 \\
\hline & & $81 \%$ & $14,3 \%$ & $4,8 \%$ & $100 \%$ \\
\hline Total & & 24 & 15 & 1 & 40 \\
\hline & & $60 \%$ & $37,5 \%$ & $2,5 \%$ & $100 \%$ \\
\hline
\end{tabular}
diperoleh, responden dengan tingkat pengetahuan baik memiliki motivasi cukup kuat sebanyak 4 orang atau $57,1 \%$, responden dengan tingkat pengetahuan cukup dengan motivasi kuat sebanyak 9 orang atau $75 \%$ dan responden dengan tingkat pengetahuan kurang dan motivasi cukup kuat sebanyak 17 orang atau $81 \%$. Untuk mengetahui besarnya hubungan yang diperoleh, dengan menggunakan bantuan program SPSS for windows versi 15.0.

Berdasarkan perhitungan diperoleh nilai korelasi Spearman 
Rho sebesar 0,608 dan $\mathrm{p}$ value $=$ 0,000 . Hal ini berarti $\mathrm{Ha}$ diterima atau dengan kata lain ada hubungan tingkat pengetahuan ibu hamil dengan motivasi ibu mengkonsumsi tablet besi di PMB Luh Putu Yuniasih, S.ST.

\section{PEMBAHASAN}

Berdasarkan hasil penelitian diperoleh yang memiliki tingkat pengetahuan baik sebanyak 7 orang atau $17,5 \%$, tingkat pengetahuan cukup sebanyak 12 orang atau $30 \%$ dan sebanyak 21 orang atau $52,5 \%$ tingkat pengetahuan kurang. Ini berarti sebagian besar responden di PMB Luh Putu Yuniasih, S.ST memiliki tingkat pengetahuan kurang. Menurut peneliti kurangnya pengetahuan yang dimiliki disebabkan karena responden belum paham manfaat zat besi selama kehamilan sebagai akibat kurangnya perolehan informasi mengenai fungsi tablet besi, menurut responden terkadang mereka memilih tidak mengkonsumsi tablet besi karena alasan efek samping yang ditimbulkan yang mengganggu aktifitas keseharian mereka.

Menurut Notoatmodjo, (2012), pengetahuan diartikan sebagai hasil tahu, dan ini terjadi setelah orang melakukan penginderaan terhadap suatu objek tertentu (Susiloningtyas, 2012). Berdasarkan hasil penelitian diperoleh bahwa responden dengan motivasi kategori cukup sebanyak 24 orang atau $60 \%$, motivasi kuat sebanyak 15 orang atau $37,5 \%$, dan motivasi tidak kuat sebanyak 1 orang atau 2,5\%. Hal ini berarti sebagian besar responden di PMB Luh Putu Yuniasih, S.ST memiliki motivasi cukup kuat.
Menurut penulis ada keterkaitan motivasi dengan latar belakang pendidikan responden, karena sebagian besar tingkat pendidikan responden adalah kategori menengah. Pengetahuan juga berperan sangat penting untuk meningkatkan motivasi seseorang. Makin tinggi tingkat pengetahuan seseorang akan meningkatkan motivasi yang ada dalam diri seseorang (Betsy W, 2015). Pengetahuan yang baik dan motivasi dalam diri seseorang akan mampu mendorong seseorang dengan dorongan yang terarah agar terjadi perubahan energi dalam diri seseorang yang ditandai dengan munculnya "feeling" sehingga pada akhirnya mau melakukan sesuatu dalam memenuhi kebutuhan psikis dan rohaniah (Adiputro, 2019). Pengetahuan yang baik juga meningkatkan pemahaman seseorang sehingga lebih cepat menerima informasi misalnya informasi tentang manfaat mengkonsumsi tablet besi selama kehamilan (Madugu et al., 2020).

\section{KESIMPULAN}

Terdapat hubungan yang kuat antara pengetahuan dan motivasi di PMB Luh Putu Yuniasih, S.ST. hal ini menunjukkan pengetahuan merupakan penentu adanya motivasi pada ibu hamil dalam mengkonsumsi tablet besi.

\section{DAFTAR PUSTAKA}

Adiputro, Y. (2019). Relationship between Motivation, Knowledge, and Availability with the Use of Personal Protective Equipment. The Indonesian Journal of Occupational Safety and Health, $8(2), \quad 124$. 
https://doi.org/10.20473/ijosh .v8i2.2019.124-130

Ari Madi Yanti, D., Sulistianingsih, A., \& Keisnawati. (2015). Faktor-Faktor Terjadinya Anemia pada Ibu Primigravida di Wilayah Kerja Puskesmas Pringsewu Lampung. Jurnal Keperawatan, 6(2), 79-87.

Badan Pusat Statistik. (2015). Angka Kematian Ibu (pp. 335-358). https://doi.org/10.1055/s2008-1040325

Badan Pusat Statistik. (2017). Badan Pusat Statistik (pp. 335-358). https://doi.org/10.1055/s2008-1040325

Betsy W. Williams. (2015). Relationship Among Knowledge Acquisition, Motivation to Change, and Self-Efficacy in CME Participants. 28(3), 157-164. https://doi.org/10.1002/chp

BPPD Banten. (2019). Strategi Penurunan Kematian Ibu Dan Anak. Journal of Chemical Information and Modeling, 53(9), 1689-1699.

Cherry, K. (2015). Mother's day. In Kenyon Review (Vol. 33, Issue 2, pp. 4-19). https://doi.org/10.7326/00034819-128-9-19980501000016

Kemenkes RI. (2012). Profile Kesehatan Indonesia. In Ministry of Health Indonesia.

Kementerian Kesehatan Republik Indonesia. (2020). Pedoman Pemberian Tablet Tambah Darah (TTD) Bagi Ibu Hamil. 24.

Khoiriah, A., \& Latifah. (2020). Pemberian Tablet Zat Besi (Fe) Pada Ibu Hamil Di Posyandu Mawar Berduri Rt
05 Kelurahan Tuan Kentang Kecamatan Jakabaring Kota Pelembang. Jurnal Pengabdian Masyarakat Kebidanan, 2(1), 1-8. http://103.97.100.145/index.p $\mathrm{hp} / \mathrm{JPMK} /$ article/view/5360/4 698

Lestari, E. D. (2017). Faktor-Faktor yang Memengaruhi Kepatuhan Ibu Hamil dalam Mengonsumsi Tablet $\mathrm{Fe}$ di Puskesmas Danurejan 1 Kota Yogyakarta.

Madugu, U., Abdul Manaf, H., Nasir, S. A., Ananthan, S. S., \& Hidayati, M. (2020). Towards a Better Understanding on the Relationship between Knowledge Sharing and Public Service Motivation. Journal of Governance and Development (JGD), 16(Number 2), 41-67. https://doi.org/10.32890/jgd2 020.16.2.3

Nurohmi, S., Pibriyanti, K., \& Sari, D. D. (2021). Efektivitas Suplementasi Zat Besi Dan Vitamin C Untuk Memperbaiki Status Anemia Santri. Media Gizi Mikro Indonesia, 12(2), 93-106. https://doi.org/10.22435/mgm i.v12i2.3856

Paendong, F. T., Suparman, E., \& Tendean, H. M. M. (2016). Profil zat besi (Fe) pada ibu hamil dengan anemia di Puskesmas Bahu Manado. ECliniC, 4(1). https://doi.org/10.35790/ecl.4 .1.2016.10985

Prabhakara, G. (2019). Health Statistics (Health Information System). In Short Textbook of Preventive and Social 
Putu Ayu Dina Saraswati: Hubungan Tingkat Pengetahuan Ibu Hamil tentang Tablet Besi dengan Motivasi Ibu Mengkonsumsi Tablet Besi di PMB Ni Luh Putu Yuniasih, S.ST.

Medicine.

https://doi.org/10.5005/jp/boo

$\mathrm{ks} / 112575$

Prasetyani, D., Apriani, E., \& Halimatusyadiyah, R. (2020). Hubungan Asupan Protein, Zat Besi Dan Pola Makan Terhadap Kejadian Anemia Pada Ibu Hamil Trimester Iii Di Wilayah Kerja Puskesmas Cilacap Utara 2. Tens: Trends of Nursing Science, 1(1), 29-35. https://doi.org/10.36760/tens.

v1i1.108

Susiana, S. (2019). Angka Kematian Ibu: Faktor Penyebab Dan Upaya Penanganannya.

Susiloningtyas, I. (2012). Pemberian Zat Besi (Fe) Dalam Kehamilan Oleh: Is Susiloningtyas. Majalah Ilmiah Sultan Agung, 50, 128. 